\title{
Derleme/Review \\ Düşük Sıcaklık Zararının Asma Üzerindeki Etkileri
}

\author{
Özkan KAYA ${ }^{1 *}$, Cafer KÖSE ${ }^{2}$ \\ ${ }^{1}$ Erzincan Bahçe Kültürleri Araştırma Enstitüsü, 24060 Erzincan, Türkiye \\ ${ }^{2}$ Atatürk Üniversitesi, Ziraat Fakültesi, Bahçe Bitkileri Bölümü, 25240 Erzurum, Türkiye \\ *sorumlu yazar: kayaozkan25@hotmail.com, Tel: +90 (553) 4701308; Fax: +90 (446) 2252052
}

\begin{abstract}
Özet: Kültüre alındığı tarihten günümüze kadar tüm toplumlarda önemini koruyan asma, dünya üzerinde yetiştiricilik bakımından çok geniş alanlarda kendine yer bulmuş 1lıman iklim meyve türleri arasında yer almaktadır. Ancak yetiştiriciliğinin bu kadar geniş alanlarda yapılması, çevresel streslere daha fazla maruz kalmasını beraberinde getirmektedir. Özellikle donma noktasının altındaki düşük sıcaklıklar asmanın yeryüzündeki dağılımını, gelişimini ve verimini etkileyen en önemli çevresel stres faktörlerinin başında gelmektedir. Sonbahar, ilkbahar ve kış aylarında meydana gelebilen düşük sıcaklıklar, yetiştiriciliğin yapıldığı birçok alanda asmanın kök, gövde, kol, dal ve göz gibi organlarında telafisi olmayan hasarlar oluşturabilmektedir. Böylesi bir durum asma yetiștiricilerini, üzüm üretimine dayalı işleme ve sanayi kuruluşlarını önemli derecede kayıplara uğratmaktadır. Bu gibi alanlarda dondurucu soğukları önlemek ya da tolere etmek için, asmanın aklimasyon, dayanıklılık ve deaklimasyon evrelerindeki donma mekanizmasının iyi bilinmesi gerekmektedir. Asmanın doku ve organlarının içinde bulunduğu bu evrelerdeki donma mekanizmasının belirlenmesi ise uygun ölçüm tekniklerinin kullanılması ile mümkün olmaktadır. $\mathrm{Bu}$ çalışmada, sıfııın altındaki sıcaklıklara maruz kalan bazı asma tür ve çeşitlerinin doku ve organlarında meydana gelen düşük sıcaklık hasarı ve uygun ölçüm teknikleri kullanılarak belirlenmiş olan don tolerans seviyeleri hakkında bilgiler derlenmiştir.
\end{abstract}

Anahtar kelimeler: Asma, Düşük sıcaklık exotermi, Termal analiz, Vitis spp.

\section{Effects of Cold Damage on Grapevine}

\begin{abstract}
From the date of its cultivation to the present day, grape preserves its importance in all societies as well as being one of the temperate climate fruit species found in a wide range of cultivated places in the world. Because of the large area cultivation and their natural structure these are exposed more environmental stresses. Especially low temperatures below freezing point affects the development and yield of the distribution of grapes on the earth. Low temperatures that can occur in autumn, spring and winter may form irreversible damage in grape root, trunk, arm, and buds organs in many areas where cultivation is done. Such a situation can result in reduced yield and substantial economic losses to grape growers, subsequently impacting fruit wholesalers, distributors, vineries and related industries. To prevent or tolerate low temperature damage must be well known of the inherent freezing tolerance of a grape cultivar at all stages of development and the interaction of environment with the acclimation, hardening and deacclimation characteristics of the grapevine in such areas. The determination of the freezing mechanism in these phases, which are found in the tissues and organs of grapevine, is made possible by the use of appropriate measurement techniques. In this study, information about the low temperature damage occurring in tissues and organs of some grape species and cultivars when exposed to temperatures less than zero and the frost tolerance levels were determined by using appropriate measurement techniques were compiled.
\end{abstract}

Keywords: Grapevine, Low temperature exotherm, Thermal analysis, Vitis spp.

\section{Giriş}

Dünyada 7.1 milyon hektar alanda yetiştirilen asma, 74.4 milyon ton üzüm üretim miktarı ile önemli bir yere sahiptir (FAO 2017). Asma yeryüzünde var olan yedi kitanın altısında yetişebilmekte ve iklimlerdeki değişimlere bağlı olarak kuzey yarımküre'de $4^{\circ}-52^{\circ}$, güney yarımkürede $6^{\circ}-44^{\circ}$ enlem dereceleri arasındaki alanlara kadar yayllım göstermektedir (Jones ve Schultz 2016). Ancak ekonomik anlamda bağcllık, kuzey yarımkürede $11^{\circ}-52^{\circ}$, güney yarımkürede $20^{\circ}-40^{\circ}$ enlem dereceleri arasında bulunan birçok ülkede yapılabilmektedir (Mullins ve ark. 1992; Fennell 2004). Bununla birlikte bu bölgelere asmanın üretim ve 
kalitesini sınırlandıran çevresel stres faktörlerinin hakim olduğu alanların oranı azımsanmayacak kadar yüksektir (Köse ve Güleryüz 2009; Turfan ve ark. 2010). Özellikle bu bölgelerde sonbahar, ilkbahar ve kış aylarında meydana gelen düşük sıcaklıklar bağcılığın istenilen düzeyde yapılmasını sınırlandıran önemli iklim faktörlerinin başında gelmektedir (Fennell 2004; Mills ve ark. 2006; Köse ve Güleryüz 2009).

Genellikle sofralık, kurutmalık, şaraplık olarak yetiştiriciliği yapılan (Keskin ve ark. 2013) ve dünya üzüm üretiminin \%90'ından fazlasını sağlayan V. vinifera L. çeşitleri düşük kış sıcaklıklarının minimum $-25^{\circ} \mathrm{C}$ 'nin üzerinde olduğu alanlar ile sinırlıdır (Fennell 2004; Mills ve ark. 2006; Keller 2015). Bu alanlarda zaman zaman meydana gelen düşük sıcaklıklar $V$. vinifera yetiştiriciliğinde önemli oranda kayıplara neden olabilmektedir (Barka ve Audran 1997). Ayrıca zaman zaman meydana gelen şiddetli düşük sicaklıklar, omcaların gövde, dal ve göz gibi organlarında telafisi olmayan önemli zararlar oluşturabilmektedir (Barka ve Audran 1997; Fennell 2004). Bu olumsuz etkiler asma yetiştiricilerini, toptancıları, üzüm üretimine dayalı işleme ve sanayi kuruluşlarını verim ve kalite kayıplarına uğratmakla beraber şekli bozulmuş omcalara yeniden şekil vermesi gereken üreticinin zaman ve maddi kayıplarını da artırmaktadır (Dami ve ark. 2007; Zabadal ve ark. 2007). Bununla beraber düşük sıcaklıkların asma gövde ve kollarında neden olduğu hasarlar, kök kanseri veya omcanın tamamen ölümü gibi ikinci bir problemi de beraberinde getirerek verimde önemli kayıplara neden olmaktadır (Fennell 2004; Moyer ve ark. 2011). Düşük sıcaklıkların etkili olduğu bölgelerde Vitis spp. üretimi yapan yetiştiriciler tarafından don hasarını en aza indirebilmek için düşük sıcaklıklara adapte olabilecek çeşitlere önem verilmesi, hibrit çeşitler kullanılması ve $-30^{\circ} \mathrm{C}$ sıcaklığa dayanabilen kuzey Amerikan ve/veya Asya tür (örneğin; V. amurensis Rupr. V. riparia Michx. V. arizonica, V. rupestris, V. rotundifolia ve V. californica) ve çeşitleri (örneğin; Concord, Cabernet Sauvignon, Chardonnay, Reisling, Valiant, Pinot noir, Pinot gris, Pinot blanc, Muscat Hamburg vb,) arasından seçilen yeni bireyler kullanarak yetiştiricilik yapılması gerekmektedir (Alleweldt ve Possingham 1988; Hemstead ve Luby 2000; Zhang ve ark. 2012). Düşük sıcaklıklara dayanıklı ve adaptasyon kabiliyeti yüksek çeşitlerin seçiminde ise, bir çeşidin soğuğa dayanımındaki içsel mekanizmasının, aklimasyon ve deaklimason özelliklerinin ve büyüme sezonu boyunca çevre ile ilişkisinin iyi bilinmesi gerekmektedir. $\mathrm{Bu}$ nedenle çalışmamızda; sıfırın altındaki sıcaklıklara maruz kalan asma doku ve organlarında meydana gelen düşük sıcaklık hasarı ve kontrollü don testleri ile belirlenen tolerans seviyeleri mevcut litaratürler 1şı̆̆ında tartışılmıştır.

\section{Asmada Don Zararl ve Tolerans}

Asmanın dormant döneminde gövde, kol ve dallar hücre arası ve hücre için donmayı bir noktaya kadar tolere ederken kış gözleri süpersoğuma özelliği göstererek don zararından kaçınmaktadır. Sıfır derecenin altındaki düşük sıcaklıklarda gövde, kol ve dalların hücrelerinde stoplazmik kurumalar meydana geldiğinde don zararı oluşur (Pierquet ve Stushnoff 1980; Adrews ve ark. 1984; Quamme 1986). Birçok odunsu türde olduğu gibi asmalarda da dokularının düşük sıcaklıklara toleransını belirlemek için doğal arazi şartları taklit edilerek labaratuvarda kontrollü don testleri yapılmaktadır. Bu amaçla yapılan analizlerde genel olarak termal analiz yöntemi kullanılmaktadır. Termal analiz, diferansiyel sıcaklıkların başlama noktalarının seçimi ya da don olaylarının exoterm olarak adlandırılan minimum değişim bölgelerin belirlenebilmesi için bitkilerde soğuğa tolerans derecesini belirlemek amaciyla kullanılan bir tekniktir (Gerard ve Schucany 1997). Bu teknikte hücre arası ve içinde bulunan suyun donması sonucu ortaya çıkan fizyon 1sı belirlenerek don toleransı ortaya konulmaktadır (Mills ve ark. 2006). Bu durum asma bünyesindeki su içeriğinin düşük sicaklıklara tolerans ile doğrudan ilişkili olduğunu göstermektedir (Fennell 2004; Zabadal ve ark. 2007; Zhang ve ark. 2012; Grant ve Dami 2015). Nitekim pek çok türde olduğu gibi asmaların aklimasyonuna girişi ile bünyelerindeki su oranında azalma başlar ve kış ortasında bu su içeriği minimum düzeye iner. Öyleki toleransın maksimum olduğu kış ortasında asma bünyesindeki su içeriği \%50-80 oranında bir azalış göstermektedir (Keller 2015). Bu nedenle asmalar düşük sıcaklıklara derin dinlenmede oldukları kış ortasında en fazla tolerans gösterirler (Fennell 2004). Düşük kış sıcaklıların çok sert yaşandığ bölgelerde yetiştirilen farklı asma tür ve çeşitlerinin derin dinlenmede oldukları kış ortasındaki maksimum tolerans dereceleri farklılıklar göstermektedir (Çizelge 1).

\section{Asma köklerinde don zararl ve tolerans}

Sonbaharda gün uzunluğundaki kısalma ve hava sıcaklıklarındaki düşüş, asma sürgün ve kış gözlerinde aklimasyonun başlamasına neden olurken köklerde herhangi bir değişim meydana gelmemektedir. Bu durum aklimasyon yeteneği kazanamayan kökleri düşük sıcaklıklara karşı savunması hale getirerek don hasarlarından kolayca etkilenebilmelerine neden olmaktadır (Keller 2015). Genellikle asma köklerinin düşük sıcaklıklara karşı gösterdikleri tolerans dereceleri türlere göre değişmektedir. Zira $V$. vinifera ve $V$. labrusca türlerinde kökler $-6^{\circ} \mathrm{C}^{\prime}$ de hasar görürken, daha küçük hücre yapısına sahip olan $V$. amurensis türünde $-15^{\circ} C^{\prime}$ ye kadar tolerans göstermektedir. Bununla beraber Amerikan asma anaçlarının birçoğunda ise kökler $-8^{\circ} \mathrm{C}$ ile $10^{\circ} \mathrm{C}$ aralığında düşük sıcaklıklara tolerans gösterebilmektedirler (Keller 2015). 
Çizelge 1. Farklı asma tür ve çeişitlerinin derin dinlenmede oldukları kış ortasındaki maksimum tolerans dereceleri

\begin{tabular}{|c|c|c|c|c|}
\hline Çeşit & Tür & Tolerans Derecesi $\left({ }^{\circ} \mathrm{C}\right)$ & Tolerans Düzeyi & Kaynak \\
\hline Alden & $(V$. labrusca $\times V$. vinifera $)$ & -23.3 ile -28.8 & Orta derecede toleranslı & (Dami ve ark. 2005; NGR 2017) \\
\hline Alpenglow & $(V$. labrusca $\times V$. riparia $)$ & -28.8 & Toleranslı & (Hawkins 2007) \\
\hline Aurore & $(V$. lincecumii $\times V$. rupestris $\times V$. vinifera $)$ & -23.3 ile -26.1 & Orta derecede toleransli & $\begin{array}{l}\text { (Reisch ve ark. 2000; Dami ve ark. } \\
\text { 2005; NGR 2017) }\end{array}$ \\
\hline Baco Noir & $(V$. vinifera $\times V$. riparia $)$ & -23.3 ile -26.1 & Orta derecede toleranslı & (Domoto 2008; NGR 2017) \\
\hline Baltica & $\begin{array}{c}(V . \text { amurensis } \times V . \text { labrusca } \times V \text {. riparia } \times \\
\text { V.vinifera })\end{array}$ & -28.8 daha düşük & Çok toleranslı & $\begin{array}{c}\text { (Plocher ve Parke 2008; Hart 2008; } \\
\text { Hart 2008) }\end{array}$ \\
\hline Beta & $(V$. riparia $\times V$. labrusca $\times V$. vinifera $)$ & -28.8 daha düşük & Çok toleranslı & (Domoto 2008; NGR 2017) \\
\hline Bluebell & $(V$. labrusca $\times V$. riparia $)$ & -28.8 daha düşük & Çok toleranslı & (Domoto 2008; NGR 2017) \\
\hline Brianna & $(V$. labrusca $\times V$. riparia) & -28.8 daha düşük & Çok toleransli & (Clark 2004; Domoto 2008) \\
\hline Buffalo & $(V$. labrusca $\times V$. vinifera $)$ & -23.3 ile -26.1 & Toleranslı & (Domoto 2008; NGR 2017) \\
\hline Cascade & (Muhtemelen $V$. rupestris $\times V$. lincecumii) & -23.3 ile -26.1 & Orta derecede toleranslı & (Whealy 1993; Domoto 2008) \\
\hline Catawba & $(V$. labrusca $\times V$. vinifera $)$ & -23.3 ile -26.1 & Orta derecede toleransli & (Domoto 2008; NGR 2017) \\
\hline Cayuga White & $\begin{array}{c}(V . \text { labrusca } \times V . \text { lincecumii } \times V . \text { rupestri } \times \\
\text { V.vinifera })\end{array}$ & -23.3 ile -26.1 & Orta derecede toleransli & (Domoto 2008; Reisch 2008) \\
\hline Chambourcin & (Türler arası hibrit) & -17.7 ile -20.5 & Çok hassas & (Domoto 2008; NGR 2017) \\
\hline Chancellor & (Türler arası hibrit) & -26.1 ile -28.8 & Toleranslı & $\begin{array}{l}\text { (Dami ve ark. 2005; Domoto 2008; } \\
\text { NGR 2017) }\end{array}$ \\
\hline Chardonel & $(V$. vinifera $\times V$. lincecumii $\times V$. rupestris $)$ & -23.3 ile -26.1 & Orta derecede toleransli & (Reisch ve ark. 1992; Domoto 2008) \\
\hline Chelois & (Türler arası hibrit) & -23.3 ile -26.1 & Orta derecede toleranslı & (Domoto 2008; NGR 2017) \\
\hline Chontay & $(V$. riparia $\times V$. labrusca $)$ & -28.8 daha düşük & Çok toleranslı & (Marshall 2008; NGR 2017) \\
\hline Clinton & $(V$. riparia $\times V$. labrusca $)$ & -28.8 daha düşük & Çok toleranslı & (Marshall 2008; NGR 2017) \\
\hline Concord & (V. labrusca $\times$ bazı $V$. vinifera çeşitleri) & -26.1 ile -28.8 & Toleranslı & $\begin{array}{c}\text { (Hedrick ve ark. 1908; Domoto 2008; } \\
\text { NGR 2017) }\end{array}$ \\
\hline Corot Noir & $\begin{array}{c}(V . \text { vinifera } \times V \text {. labrusca } \times V \text {. rupestris } \times \\
V . \text { lincecumii } \times V \text {. riparia })\end{array}$ & -23.3 ile -26.1 & Orta derecede toleransli & (Reisch ve ark. 2006; Reisch 2008) \\
\hline Cynthiana & (V. aestivalis $\times V$. labrusca) & -23.3 ile -26.1 & Orta derecede toleranslı & (Domoto 2008; NGR 2017) \\
\hline DeChaunac & $\begin{array}{c}(V . \text { labrusca } \times V \text {. lincecumii } \times V \text {. riparia } \times \\
V \text {. rupestris } \times V \text {. vinifera })\end{array}$ & -23.3 ile -26.1 & Orta derecede toleranslı & (Domoto 2008, NGR 2017) \\
\hline Delaware & (V. labrusca melezi) & -26.1 ile -28.8 & Toleranslı & (Dami ve ark. 2005) \\
\hline Edelweiss & $(V$. riparia $\times V$. labrusca $)$ & -26.1 & Toleransli & (Swenson ve ark. 1980) \\
\hline Elvira & $(V$. riparia $\times V$. labrusca $\times V$. vinifera $)$ & -28.8 & Çok Toleranslı & $\begin{array}{l}\text { (Hedrick ve ark. 1908; Reisch ve ark. } \\
\text { 2000) }\end{array}$ \\
\hline Espirit & $(V$. vinifera $\times V$. labrusca $)$ & -26.1 ile -28.8 & Toleransli & $\begin{array}{c}\text { (Swenson 1986; Domoto 2008; NGR } \\
\text { 2017) }\end{array}$ \\
\hline
\end{tabular}




\begin{tabular}{|c|c|c|c|c|}
\hline Çeşit & Tür & Tolerans Derecesi $\left({ }^{\circ} \mathrm{C}\right)$ & Tolerans Düzeyi & Kaynak \\
\hline Fredonia & $(V$. labrusca $\times V$. vinifera $)$ & -26.1 ile -28.8 & Toleransli & (Domoto 2008; NGR 2017) \\
\hline Frontenac & $(V$. vinifera $\times V$. riparia $)$ & -28.8 daha düşük & Çok toleranslı & (Domoto 2008; NGR 2017) \\
\hline Frontenac Gris & $(V$. vinifera $\times V$. riparia $)$ & -37.2 & Çok toleranslı & (Luby ve Hemstad 2006; NGR 2017) \\
\hline GR 7 & $(V$. labrusca $\times V$. riparia $\times V$. vinifera $)$ & -28.8 daha düşük & Çok toleranslı & (Domoto 2008; NGR 2017) \\
\hline Jupiter & $($ V. labrusca $\times V$. vinifera $)$ & -23.3 ile -26.1 & Orta derecede toleranslı & (Clark ve Moore 2002) \\
\hline Kay Gray & $(V$. labrusca $\times V$. riparia $)$ & -37.2 ile -40 & Çok toleranslı & $\begin{array}{l}\text { (Swenson 1982; Plocher ve Parke } \\
\text { 2001) }\end{array}$ \\
\hline King of the North & $(V$. labrusca $\times V$. riparia $)$ & -37.2 & Çok toleranslı & (Marshall 2008) \\
\hline La Crescent & $\begin{array}{c}(V . \text { vinifera } \times V \text {. riparia } \times V \text {. rupestris } \times V \text {. } \\
\text { labrusca } \times V \text {. aestivalis })\end{array}$ & -28.8 ile -37.2 & Çok toleranslı & (Clark 2002) \\
\hline LaCrosse & $\begin{array}{c}(V . \text { labrusca } \times V . \text { lincecumii } ; V \text {. riparia } \times V \text {. } \\
\text { rupestris } \times V \text {. vinifera })\end{array}$ & -26.1 ile -28.8 & Toleranslı & (Domoto 2008) \\
\hline Landot Noir & $\begin{array}{c}(V . \text { aestivalis } \times V \text {. berlandieri } \times V \text {. cinerea } \\
\times V \text {.labrusca } \times V \text {. lincecumii } \times V \text {. riparia } \times \\
V . \text { rupestris } \times V \text {. vinifera })\end{array}$ & -23.3 ile -26.1 & Orta derecede toleranslı & (Hawkins 2007; NGR 2017) \\
\hline Léon Millot & $(V$. riparia $\times V$. rupestris $\times V$. vinifera $)$ & -28.8 ile -37.2 & Toleransli & (Reisch ve ark. 2000; Domoto 2008) \\
\hline Lemberger & (V. Vinifera) & -17.7 ile -23.3 & Hafif toleransli & (Fiola 1996; NGR 2017) \\
\hline Louise Swenson & $(V$. labrusca $\times V$. riparia $)$ & -33.3 & Çok toleranslı & (Clark 2002) \\
\hline Maréchal Foch & $(V$. riparia $\times V$. rupestris $\times V$. vinifera $)$ & -26.1 ile -28.8 & Toleransli & (Domoto 2008; NGR 2017) \\
\hline Marquette & (V. riparia $\times V$. vinifera $\times$ diğer Vitis türleri) & -28.8 ile 34.4 & Çok toleranslı & (Hemstad ve Luby 2005; NGR 2017) \\
\hline Marquis & $(V$. labrusca $\times V$. vinifera $)$ & -23.3 ile -26.1 & Orta derecede toleransli & (Domoto 2008) \\
\hline Mars & $(V$. labrusca $\times V$. vinifera $)$ & -23.3 ile -26.1 & Orta derecede toleransli & (Moore 1985; NGR 2017) \\
\hline Niagara & $(V$. labrusca $\times V$. vinifera $)$ & -23.3 ile -26.1 & Orta derecede toleranslı & (Hedrick ve ark. 1908; NGR 2017) \\
\hline Noiret & $\begin{array}{c}(V . \text { vinifera } \times V . \text { labrusca } \times V \text {. rupestris } \times \\
V . \text { riparia } ; V \text {. lincecumii })\end{array}$ & -20.5 ile 26.1 & Orta derecede toleransl 1 & $\begin{array}{l}\text { (Reisch ve ark. 2006; Reisch ve ark. } \\
\text { 2007) }\end{array}$ \\
\hline Petite Amie & $(V$. vinifera $\times V$. riparia) & -31.6 & Çok toleranslı & Macgregor 2007; Hart 2008) \\
\hline Petite Jewel & $(V$. labrusca $\times V$. riparia $\times V$. vinifera $)$ & -26.1 & Toleransli & $\begin{array}{l}\text { (Swenson 1991; Hawkins 2007; } \\
\text { Domoto 2008) }\end{array}$ \\
\hline Prairie Star & $\begin{array}{c}(V . \text { vinifera } \times V . \text { rupestris } \times V . \text { labrusca } \times \\
\text { V.aestivalis })\end{array}$ & -28.8 ile -37.2 & Toleransli & (Clark 2002; Domoto 2008 ) \\
\hline Ravat 34 & $(V$. vinifera $)$ & \%50 ölüm = -27.5 & Toleransli & (Reisch ve Luce 2005; NGR 2017) \\
\hline
\end{tabular}




\begin{tabular}{|c|c|c|c|c|}
\hline Çeşit & Tür & Tolerans Derecesi $\left({ }^{\circ} \mathrm{C}\right)$ & Tolerans Düzeyi & Kaynak \\
\hline Reliance & $(V$. labrusca $\times V$. vinifera $)$ & -23.3 ile -26.1 & Orta derecede toleranslı & $\begin{array}{l}\text { (Moore 1984; Clark 2002; Domoto } \\
\text { 2008) }\end{array}$ \\
\hline Rosette & $($ V.vinifera $\times V$. rupestris $\times V$. lincecumii $)$ & -26.1 & Toleransli & (Whealy 1993) \\
\hline Sabrevois & $($ V. labrusca $\times$ V. riparia $)$ & -35 & Çok toleranslı & (Plocher ve ark. 2008; NGR 2017) \\
\hline Seyval Blanc & $(V$. lincecumii $; V$. rupestris $\times V$. vinifera $)$ & -23.3 ile -26.1 & Orta derecede toleransli & (Fennell 2004; NGR 2017) \\
\hline Sipaska & (V. labrusca $\times$ bilinmeyen yabani türler) & -40 & Çok toleranslı & (Plocher 2007; NGR 2017) \\
\hline Skujinsh & $\begin{array}{c}(V . \text { vinifera; } \\
\text { V. amurensis } \\
\text { V.riparia })\end{array}$ & -35.5 & Çok toleranslı & (Plocher ve Parke 2001; Hart 2008) \\
\hline Somerset Seedless & $\begin{array}{c}(V . \text { labrusca } \times V \text {. riparia } \times V \text {. vinifera } \times \\
\text { American Vitis türleri })\end{array}$ & -34.4 & Çok toleranslı & (Marshall 2008) \\
\hline St. Croix & $($ V. labrusca $\times$ V. riparia $)$ & -32.7 & Çok toleranslı & $\begin{array}{l}\text { (Swenson 1982; Plocher ve Parke } \\
\text { 2001; Domoto 2008) }\end{array}$ \\
\hline St. Pepin & $\begin{array}{c}(V . \text { labrusca } \times V \text {. lincecumii } \times V \text {. riparia } \times \\
V . \text { rupestris } \times V . \text { vinifera })\end{array}$ & -31.6 & Çok toleranslı & (Plocher ve Parke 2001; NGR 2017) \\
\hline St. Vincent & (V. vinifera $\times$ bilinmeyen türler) & -23.3 ile -26.1 & Orta derecede toleransli & (Wagner 1988; Byers 2008) \\
\hline Steuben & (V. labrusca) & -26.1 ile -28.8 & Toleranslı & (Domoto 2008; NGR 2017) \\
\hline Swenson Red & $(V$. labrusca $\times$ V. riparia $)$ & -31.6 ile 34.4 & Çok toleransli & (Swenson 1991; NGR 2017) \\
\hline Swenson White & (V. labrusca $\times V$. riparia) & -28.8 daha düşük & Çok toleranslı & (Domoto 2008) \\
\hline Traminette & $\begin{array}{c}(V . \text { lincecumii } \times V \text {. rupestris } \times V \text {. vinifera } \times \\
V . \text { vabrusca } \times V \text {. riparia })\end{array}$ & -23.3 ile -26.1 & Orta derecede toleransl 1 & (Dami ve ark. 2005; Domoto 2008) \\
\hline Trollhaugen & $($ V. labrusca $\times$ V. riparia $)$ & -30 & Çok toleranslı & $\begin{array}{c}\text { (Swenson 1991; Clark ve Moore } \\
\text { 2002; Domoto 2008) }\end{array}$ \\
\hline Valiant & $($ V. labrusca $\times$ V. riparia $)$ & -45.5 & Çok toleranslı & $\begin{array}{c}\text { (Hawkins 2007; Hoover ve Hemstad } \\
\text { 2000) }\end{array}$ \\
\hline Valvin Muscat & $(V$. vinifera $\times V$. rupestris $)$ & -20.5 ile -26.1 & Orta derecede toleransli & (Reisch ve ark. 2006) \\
\hline Van Buren & (V. labrusca $\times V$. vinifera $)$ & -26.1 ile -28.8 & Toleransli & (Domoto 2008; NGR 2017) \\
\hline Vanessa & $(V$. labrusca $\times V$. vinifera $)$ & -23.3 ile -26.1 & Orta derecede toleransli & (Fishe ve Brad 1985; Domoto 2008) \\
\hline Veeblanc & $\begin{array}{c}(V . \text { vinifera } \times \text { muhtemelen } V \text {. rupestris } \times \\
\text { V.lincecumii })\end{array}$ & -23.3 & Orta derecede toleransli & (Domoto 2008) \\
\hline Ventura & $(V$. labrusca $\times V$. riparia $\times V$. vinifera $)$ & -28.8 daha düşük & Çok toleransli & (Domoto 2008) \\
\hline Vignoles & $(V$. vinifera $\times V$. lincecumii $\times V$. rupestris $)$ & -23.3 ile -26.1 & Orta derecede toleranslı & (Domoto 2008; NGR 2017) \\
\hline Worden & $(V$. labrusca $\times$ bazı $V$. vinifera $)$ & -40 & Çok toleransli & (Hedrick ve ark. 1908) \\
\hline Zilga & $\begin{array}{c}\text { (Muhtemelen } V \text {. amurensis } \times V \text {. labrusca } \times \\
V \text {. vinifera melezi) }\end{array}$ & -40 & Çok toleranslı & (Plocher ve Parke 2001; Hart 2008) \\
\hline
\end{tabular}


Ancak türlere göre tolerans derecesi değişim gösterse de toprak sıcaklığının $-4^{\circ} \mathrm{C}$ ve altına düşmesi asma kök dokularında don zararı hassasiyetini artırdığı bilinmektedir (Fennell 2004). Buna rağmen kök dokularında don zararı sıklıkla meydana gelen bir olay değildir. Çünkü toprak ve kar örtüsünün koruyucu etkisi asma kök dokularının don zararından korunmasında önemli bir role sahiptir (Gao ve ark. 2014). Ancak kar örtüsünden noksan ve su içeriğinin yüksek olduğu topraklarda derin toprak donmaları oluştuğunda önemli oranda kök zararı oluşabilir (Gao ve ark. 2014). Bununla beraber suyun 1sınma kapasitesi, havadan daha yüksek olduğu için kurak topraklar nemli topraklara oranla daha fazla sıcaklık dalgalanmaları gösterecektir. Bu nedenle kışın yetersiz toprak nemi de asma köklerini don zararına uğratabilmektedir (Keller 2015). Bu nedenle kışları soğuk yazları kurak geçen bölgelerdeki yetiştiriciler sonbaharda bağ alanlarında omcaların gövdelerini $30 \mathrm{~cm}$ kadar toprağa gömmekte ve kök bölgesinin yeniden nem kazanması için tarla kapasitesine kadar sulama yapmaktadır (Keller 2015). Buna karşın ekstrem düşük kış sıcaklıklarının sürekli olduğu daha güney ve daha kuzey alanlarda, bazen köklerde kısmi veya kökün tamamında düşük sıcaklık hasarları meydana gelebilmektedir (Ahmedullah 1985). Bu alanlarda köklerin tamamında meydana gelen don omcanın ölümüne neden olurken, kısmi kök donları kök basıncını engelleyerek göz ve ksilem dokularının su alımını kısıtlayarak ilkbaharda düzensiz göz patlamaları ve vejetatif gelişmede gerilemelere neden olmaktadır (Ahmedullah 1985; Pagter ve Arora 2013). Diğer yandan genç omcalar düşük sıcaklık zararına karşı yaşlı omcalara göre daha hassastır. Bu durum genç omca köklerinin yaşlı omca köklerine göre toprakta az gelişimi ve daha yüzeysel oluşuyla ilişkilidir (Fennell 2004).

Kontrollü don testleri asma köklerinde ilk olarak floem ardından ksilem dokularının donduğunu göstermektedir. Floem dokusunun, büyük oranda hücreler arası boşluklara sahip ve gevşek yapıda dizilmiş birçok canlı parankima hücre tabakasından meydana gelmesi, düşük sıcaklık zararı hassasiyetini artırmaktadır. Diğer yandan ölü hücrelerden meydana gelen ksilem borularının, aktivitesi düşük daha sıkı ve kalın hücre duvarlarına sahip olması ise, don anında dehidrasyona karşı koruyucu bir mekanizma oluşturarak hücrelerde membran çatlaması ve plazma deformasyonuna engel olmaktadır (Gao ve ark. 2014). Bununla birlikte asmada köklerin kesitsel anatomik yapıları incelendiğinde, soğuğa dayanıklılığın floem çapı ile ters, ksilem çapı ile doğru orantılı olduğu görülmektedir (Guo ve ark. 1989). Nitekim kök exoderm tabakası kalın, floemi ince ve ksilem oranı fazla olan çeşitler diğer çeşitlere nazaran daha fazla soğuğa toleranslı bulunmuştur (Gao ve ark. 2014). Bu nedenle asma köklerindeki floem ve ksilem zararı tür ve çeşitler arasında soğuğa dayanım seviyesini belirlemede morfolojik bir indikatör olarak kullanılmaktadır (Çizelge 2). Ancak son çalışmalar daha kalın ve fazla ksilem dokusuna sahip asmaların daha ince ve az ksilem dokusuna sahip olan asmalara göre çok daha fazla soğuğa toleranslı olduğunu gösterse de; ksilem hücrelerinin dayanımdaki rolleri ve ksilemdeki su içeriği ile borucuk sayısı gibi ksilemin kalınlığının dışında diğer faktörlerin de soğuğa toleranslılık üzerinde önemli roller üstlenip üstlenmediklerini belirlemek amacıyla daha fazla çalı̧̧manın yapılmasını zorunlu hale getirmektedir.

\section{Gövdedeki don zararl ve tolerans}

Omcanın dik durmasında, kökler ile dallar arasındaki bağlantıyı sağlamada ve besin maddelerinin depolanmasında görev alan gövde, genel olarak düşük sıcaklıklara en fazla tolerans gösteren organdır. Ancak sonbahar erken donları ya da şiddetli ve/veya dalgalı kış sıcaklıklarının görüldüğü pek çok yetiştirme bölgesinde, zaman zaman asma gövdesinde don zararı veya gövde ölümleri meydana gelebilmektedir (Ahmedullah 1985; Hamman 1993; Meiering ve ark. 1980; Mullins 1986; Paroschy ve ark. 1980; Wolf ve Warren 2000). Bu alanlarda sıcaklık dalgalanmalarının neden olduğu donma erime olayları her zaman asma gövdesinde zarar oluşturmayabilmektedir. Ancak asma gövdesinde zarar oluşmasa bile kol, dal ve göz gibi organlarda önemli derecede don hasarı görülebilir (Fennell 2004). Özellikle sonbaharda aklimasyona geç giren omcalar gövdelerinde yüksek oranda su içerdiklerinden dolayı bu tip don hasarlarına daha fazla maruz kalmaktadır. Bununla beraber erken aklimasyona giren ya da çok düşük sıcaklıklara toleranslı çeşitlerin gövdelerinde de bazen don hasarları görülebilmektedir (Paroschy ve ark. 1980).

Bağın kurulduğu alan içerisinde ve asma gövdesinde meydana gelen düşük sıcaklık hasarının lokal olarak belirlenmesi zordur. Ancak gövde ve dallarda düşük sıcaklık hasarı floem ve ksilem gibi vasküler dokularda meydana gelmektedir (Moyer ve ark. 2011). Bu dokularda düşük sıcaklık hasarı, ilk olarak floem dokusunun girişinde, daha sonra kambiyum ve ardından ksilem ışın hücrelerinde meydana gelen ölümler ile kendini göstermektedir (Şekil 1) (Pool 2002b). Floem dokusunda şiddetli don hasarı meydana gelse bile bu dokular zaman içerisinde kendini onarabilmektedir (Keller ve Mills 2007), ancak floem dokusundaki hasarın oranına bağlı olarak, ilkbaharda gözlerin tamamının patlamaması, zayıf göz patlaması ya da yeni gelişen sürgünlerde yetersiz karbonhidrat birikiminden dolayı bodur büyüme sonuçları ile karşılaşılabilir (Fennell 2004). Diğer yandan ksilemde oluşan düşük sıcaklık hasarı ise yıkıcı olabilir. Zira, şiddetli ksilem hasarının görüldüğü omcalarda ilkbaharda normal göz patlamaları olabilir, ancak transprasyonun yüksek olduğu dönemde 
köklerden kanopiye taşınan su yetersiz olacağından, bu durum organların bir kısmının ya da omcanın tamamının ölümü ile sonuçlanabilir (Moyer ve ark. 2011; Keller 2015). Bununla beraber düşük sıcaklık hasarı yalnızca gözlerde meydana gelmiş ise, omca yaşamını devam ettirmek adına canlı olan floem ve ksilem dokularından yeni vasküler kambiyum veya bölünen vasküler kambiyum uyartımları ile aktif göz büyümesi ve göz patlamasına neden olarak büyümeyi daha fazla sınırlandırmaktadır (Pool 2002b). Ayrıca zarar görmüş bir omcanın kendini onarabilmesi, vejetasyon süresinin uzunluğu ve ardından gelen dinlenme dönemindeki düşük sıcaklık zararının tekrarlanıp tekrarlanmadığı ile doğrudan ilişkilidir (Keller ve Mills 2007). Genellikle kısa bir büyüme mevsiminde dokular yeterince pişkinleşemeyeceğinden zararın tekrar etmesi halinde omcada ölüm meydana gelebilir (Mullins 1986). Diğer yandan asma gövdesinde meydana gelen düşük sıcaklık hasarı, aşırı dip sürgünü oluşumu, kök uru gelişimi, gövde çatlamaları gibi etkenleri de beraberinde getirmektedir (Moyer ve ark. 2011).

Çizelge 2. Anaç ve çeşitlere ait köklerin düşük sıcaklıklara tolerans düzeyleri $\left({ }^{\circ} \mathrm{C}\right)$

\begin{tabular}{|c|c|c|c|c|}
\hline Anaç ve çeşitler & $\begin{array}{l}\text { \%50 floem } \\
\text { zararı }\left({ }^{\circ} \mathrm{C}\right)\end{array}$ & $\begin{array}{l}\text { \%100 floem zararı } \\
(\circ \mathrm{C})\end{array}$ & $\begin{array}{l}\text { \%50 ksilem zararı } \\
(\circ \mathrm{C})\end{array}$ & $\begin{array}{l}\text { \%100 ksilem zararı } \\
(\circ \mathrm{C})\end{array}$ \\
\hline Tannat & -4.78 & -6.77 & -9.65 & -12.52 \\
\hline Dorn felder & -5.34 & -7.11 & -9.30 & -11.47 \\
\hline Carmenere & -5.55 & -7.37 & -12.1 & -16.86 \\
\hline Syrah & -6.21 & -8.09 & -11.4 & -14.84 \\
\hline Riesling & -6.14 & -8.71 & -12.72 & -16.72 \\
\hline Vidal & -6.67 & -9.49 & -12.14 & -14.79 \\
\hline 110R & -6.69 & -9.29 & -12.31 & -15.32 \\
\hline Merlot noir & -6.94 & -9.03 & -12.11 & -15.19 \\
\hline $1103 \mathrm{P}$ & -6.83 & -9.92 & -12.78 & -15.64 \\
\hline Summer Black & -7.35 & -9.64 & -12.17 & -14.69 \\
\hline $140 \mathrm{Ru}$ & -6.86 & -10.03 & -13.33 & -16.63 \\
\hline Beck memento & -7.18 & -10.14 & -14.48 & -18.81 \\
\hline Chambourcin & -7.24 & -10.46 & -14.37 & -18.28 \\
\hline $101-14 \mathrm{M}$ & -7.57 & -11.20 & -13.66 & -16.11 \\
\hline $5 B \mathrm{~B}$ & -7.75 & -10.55 & -13.51 & -16.46 \\
\hline 3309C & -8.30 & -10.94 & -13.60 & -16.26 \\
\hline Dogridge & -7.93 & -11.18 & -14.66 & -18.14 \\
\hline Golden Queen & -8.55 & -11.00 & -13.74 & -16.47 \\
\hline $\mathrm{SO} 4$ & -8.35 & -11.84 & -14.55 & -17.26 \\
\hline Frontenac & -9.60 & -14.30 & -17.72 & -21.13 \\
\hline Beta & -10.4 & -14.61 & -18.48 & -22.34 \\
\hline
\end{tabular}

Kaynak: (Gao ve ark. 2014)

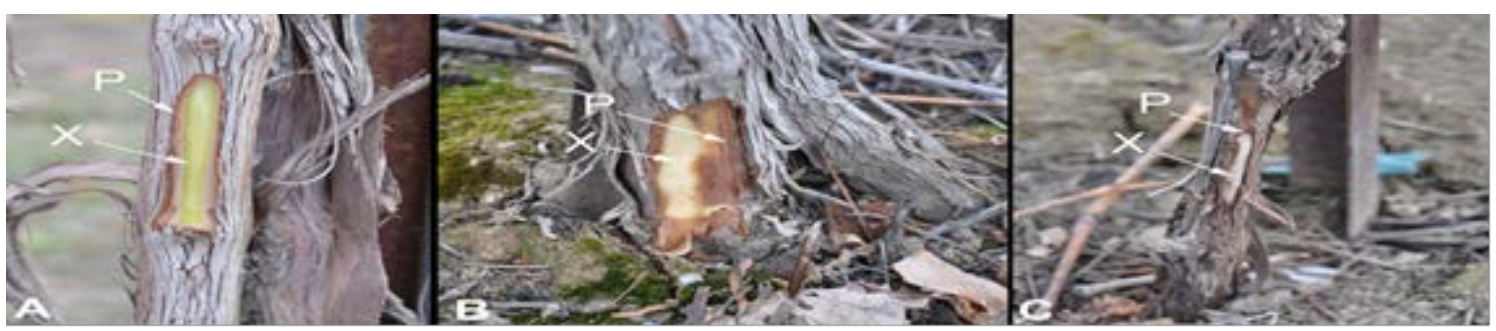

Şekil 1. Floem (P), ksilem (x). Gövdede soğuk zararı (A) floem ölmüş fakat yeşil görünen ksilem canlı (B) floem ölü fakat ksilemde kısmen (süt beyazı) zararlanma var (C) hem foloem hem de ksilem ölmüş (Moyer ve ark. 2011). 


\section{Kol ve daldaki don zararl ve tolerans}

Asma doku ve organları düşük sıcaklıkları tolere etme özellikleri bakımından farklıklar göstermektedir. Zira, asma gövdesinden sonra düşük sıcaklıklara en fazla tolerans gösteren kol ve dallar soğuğa maruz kaldıklarında, ya hücreler arası donmayı tolere ederek ya da süpersoğuma özelliği göstererek don zararından korunabilir (Hamman ve ark. 1990; Pierquet ve ark. 1977; Pierquet ve Stushnoff 1980; Quamme 1995). Ancak kol ve dallar ölümcül derecedeki düşük sıcaklıklara karşı koyabilmeleri için gelişim evreleri ve doku tipi en belirleyici etkendir. Örneğin sonbaharda hava sıcaklıklarının $-3^{\circ} \mathrm{C}^{\prime}$ ye yaklaşmasıyla Concord (V. labruscana L. H. Bailey) çeşidinde sürgün pişkinleşmesinin başladığı ve kış ortasında $-15^{\circ} \mathrm{C}$ 'ye ulaşan hava sıcaklıkları ile sürgün pişkinleşmesinin tamamlanarak don toleransının arttığı görülmüştür (Wolpert ve Howell 1986a; Fennell 2004). Diğer yandan asma kök ve gövde dokuları ile benzer özellik gösteren kol ve dalların floem dokuları, don zararına karşı çok hassas, ksilem dokuları ise daha toleranslıdır (Pierquet ve Stushnoff 1980; Slater ve ark. 1991). Bununla birlikte düşük sıcaklıklar kol ve dalların ksilem dokularında şiddetli bir hasara neden olmuşsa, baharda omcanın taç gelişimi için gerekli olan su taşınımı yetersiz olacağı için omca ölümleri meydana gelebilir. Ayrıca don zararının şiddetine bağlı olarak sürgün dokularında yıkımlar ve bodurlaşmalar da görülebilir. Bu yüzden kol ve dallarda ksilem hasarı daha tehlikelidir. Ancak sıfır derecenin altındaki hava sıcaklıkları kol ve dallarda soğuğa aklimasyon özelliğini harekete geçirir ve kışın dormant sezon içerisinde soğuğa tolerans düzeyi maksimum düzeye ulaşır. K1ş boyunca floem dokusunun dona tolerans derecesi $-15^{\circ} \mathrm{C}$ ile $-32^{\circ} \mathrm{C}$ 'deki sıcaklık aralığında değişim gösterir ve bu aralık çeşit farklılıkları ile omcanın daha önce maruz kaldığı sıfırın altındaki sıcaklık farklılıklarından kaynaklanmaktadır (Fennell 2004). Diğer yandan derin dinlenme dönemi olan kış ortasında floemden daha toleranslı olan ksilem dokuları ise, $-20^{\circ} \mathrm{C}$ ile $-50^{\circ} \mathrm{C}$ 'deki sicaklıklara kadar tolerans gösterebilmektedir (Rajashekar ve Burke 1996). Genel olarak V. vinifera, V. labruscana ve hibrit çeşitlere ait dallar dönemlere bağlı olarak değişmekle beraber $-8^{\circ} \mathrm{C}$ ile $-25^{\circ} \mathrm{C}$ aralığında düşük sıcaklıklara tolerans gösterir (Jones ve ark. 1999; Fennell 2004). Düşük sıcaklıklara tolerensı artan dallar üzerinde bulunan kış gözleri soğuklama ihtiyacını tamamladıkları için hava sıcaklıklarındaki artış uyanmayı başlatır. Gözlerin uyanması ile büyümeye başlayan sürgünlerde düşük sicaklıklara tolerans yaklaşı $-4^{\circ} \mathrm{C}$ civarındadır (Fennell 2004). Asma dalarında aklimasyonun başladığı ve pişkinleşmenin meydana geldiği evrede, kanopinin iç kısımlarında bulunan dallarda pişkinleşme daha yavaş ilerler ve sonbaharda sık sık oluşan mevsim dişı düşük sıcaklıklara maruz kalan bu dallarda don zararı meydana gelir (Keller ve Mills 2007). Dallardaki olgunlaşma derecesi dış kabuk dokusunun gelişmesine bağlı olarak sürgün renginin yeşilden sarıya ve kahverengileşmeye geçişi ile gözlenebilir (Fennell ve Hoover 1991). Bununla birlikte çubuğun apikal kısmı bazal kısmına oranla daha yüksek su ihtiva ettiği için mevsim dışı sıcaklık düşüşlerinde donlara karşı daha hassas olur (Fennell 2004) fakat baharda yapılan kış budamasında genel olarak apikal kısımlar çıkarıldığı için böylesi bir durum verim kayıplarını tehdit edici bir zarara neden olmaz. Ancak sonbahar erken donları vejetatif olarak olgunlaşmasını tamamlayamayan yeşil veya sarı çubuklarda tüm çubuk dokusunun ölümüne neden olabilir. Benzer şekilde kışın veya erken ilkbaharda ekstrem düşük sıcaklıklar floem dokusuna zarar verebildiği gibi omcada ölüme neden olup büyüme sezonunda verimde ciddi kayıplar da oluşturabilir (Keller 2015).

\section{Gözdeki don zararl ve tolerans}

Asmada dinlenme sezonu süresince kış gözleri, dal ve gövdelere oranla düşük sıcaklık zararına karşı daha hassastır (Quamme 1986). Kış gözlerinin dondurucu sıcaklıklara toleransı, aklimasyon, dayanıklılık ve deaklimasyon dönemlerine göre değişiklik göstermektedir. Sonbaharda azalan hava sıcaklıkları ile beraber gün uzunluğundaki kısalma gözlerde aklimasyon ve pişkinleşmeyi başlatmaktadır. Gözlerde pişkinleşme tek yıllık sürgünün bazalındaki ilk gözden başlayarak sürgünün yukarısında bulunan gözlere doğru ilerlemektedir (Fennell ve Hoover 1991). Bununla birlikte tek yıllık sürgünler ile benzer özellik gösteren apikal göz, bazalda bulunan gözlere oranla düşük sıcaklıklara karşı daha hassastır (Fennell ve Hoover 1991). Benzer şekilde sürgün üzerindeki kış gözlerin düşük sıcaklıklara karşı tolerans sıralaması yapıldığında apikal gözler orta gözlere, orta gözler ise bazal gözlere oranla daha hassastır (Grant ve Dami 2015; Köse ve Kaya 2017). 


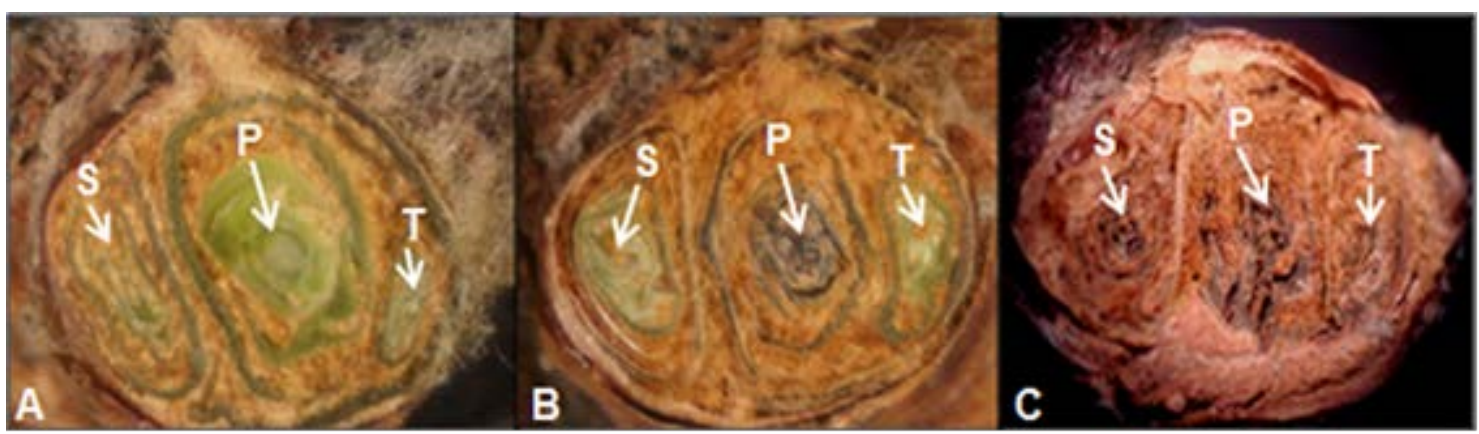

Şekil 2. Asmada karışık göz yapısının enine kesiti (primer, sekonder ve tersiyer tomurcuklar) (A) tüm tomurcuklar canlı (B) primer tomurcuk ölü (C) öldürücü sıcaklık sonucu tüm tomurcuklar ölmüş (Moyer ve ark. 2011).

Kış gözü içerisinde sürgün oluşturma yeteneğine sahip olan 3 adet sürgün yatağına mevcuttur. Bu sürgün yatakları primer, sekonder ve tersiyer tomurcuklar olarak adlandırılır (Şekil 2). Bu tomurcuklar düşük sicaklıklara hassasiyet bakımından sirasıyla en hassas primer ardından sekonder ve tersiyer tomurcuklar şeklindedir (Hemstead ve Luby 2000). Primer tomurcukların salkım taslağı fazla olduğundan, yetiştriciler daha fazla ürün almak için genellikle bu tomurcukların sağlıklı olmasını temenni ederler. Primer tomurcukların zararlanması halinde sekender tomurcuklar sürer, fakat sekonder tomurcuklar primer tomurcuklardan daha küçük salkım taslaklarına sahiptir (Goffinet 2004). Ayrıca bazı araştırıcılar, French-Amerikan hibritlerinin (Chambourcin, Corot noir Esprit, Mars, Seyval blanc, Chancellor, De Chaunac vb, ) primer tomurcuklarda meydana gelen hasar sonucu süren sekonder tomurcukların, ana ürün kayıplarını \%50-70 oranında telafi ettiğini dile getirmektedirler (Zraly 2016). Diğer yandan Chardonnay üzüm çeşidinin hem primer hem de sekonder tomurcuklarında iki adet salkım taslağının bulunduğu ve sekonder tomurcukların ana ürünün \%39'unu karşıladığı ifade edilmektedir (Friend ve ark. 2006). Benzer şekilde üç farklı türün melezi olan Marechal Foch' $(V$. riparia $\times V$. rupestris $\times V$. vinifera) üzüm çeşidinin sekonder tomurcuklarının verimli olduğu da görülmüştür (Zraly 2016). Ancak bazı çeşit ve türlerde sekonder tomurcuklar verimli olsa da genel olarak kış gözü içerisinde primer tomurcukların en düşük sıcaklıklara tolerans gösterme dereceleri dayanıklılık değerlendirilmesinde dikkate alınmaktadır (Smiley ve ark. 2008).

Asma kış gözlerinin vejetasyon ve dormant sezon içerisinde düşük sıcaklıklara tolerans aralıkları $-2^{\circ} \mathrm{C}$ ile $42^{\circ} \mathrm{C}$ kadar değişim göstermektedir (Bordelon ve ark. 1997). Sezon içerisinde kış gözünün düşük sıcaklıklara toleransı, aynı bölgede yetişen aynı çeşitler ya da farklı bölgede yetişen aynı çeşitler arasında bile değişmektedir (Bordelon ve ark. 1997). Bununla birlikte aynı asmanın dalları arasında ve dalların da tepe kısımları ile dip kısımları arasında bile düşük sıcaklıklara toleransta önemli farklılıklar oluşmaktadır (Köse ve Kaya 2017; Kaya ve Köse 2017). Çeşitlerden V. vinifera $\times$ V. rotundifolia Michx. $\times$ V. vinifera'nın hibritleri $V$. riparia $\times V$. labruscana genotiplerine oranla düşük sıcaklıklara toleransta daha hassastır. Gözlerin uyanmasıyla oluşan yeşil renkli sürgünler üzerinde bulunan kış gözlerinin düşük sıcaklıklara toleransı $-2^{\circ} \mathrm{C}$ ile $-4^{\circ} \mathrm{C}$ aralığındadır (Fennell 2004). Diğer yandan gün uzunluğundaki azalış kış gözlerinin dinlenmeye girişi üzerine doğrudan etki etmektedir. Ayrıca gün uzunluğundaki değişim aralıkları üzüm çeşitlerinin sürgünlerinde pişkinleşme ve kış gözlerinde aklimasyonun başlamasını farklı derecelerde etkileyerek düşük sıcaklıklarda hayatta kalma sürelerini de değiştirmektedir (Mullins 1986). Nitekim gün uzunluğuna duyarlı olan çeşitler düşük sıcaklıklara maruz kaldığında gözlerde dona toleransı artarken duyarlı olmayan çeşitlerde soğuğa aklimasyon ve dormansi olayları teşvik edilir (Schnabel ve Wample 1987). Dormansi ve aklimasyon uyartımları ile kış gözlerinin su içeriğinde azalma meydana gelir (Fennell 2004). Su içeriği sonbaharın başında sürgün üzerindeki bazal gözlerde en düşük ve apikal gözlerde ise en yüksek seviyededir. Kış soğuklarının başlaması ile gözlerde su içeriği iyice azalmaya başlar, dayanıklılığın en fazla olduğu derin dinlenme döneminde minimum seviyeye ulaşır. Bununla beraber baharda sıcaklıkların artışı gözlerde deaklimasyonu başlatarak su içeriğinin yeniden yükselmesine neden olur (Fennell 2004). Düşük sicaklıklara maruz kalan bu gözler bünyelerindeki mevcut suyun donması sonucu zara görür ve su donarken doku sıcaklığında ani bir artış görülür. Donma esnasında ortaya çıkan bu füzyon sıcaklığı, ekzoterm sıcaklığı olarak ifade edilir (Quamme 1991). Dokularda hücre arası suyun aşırı soğuması ile bu bölgede buz kristalleri oluşmaya başlar ve yüksek sıcaklık ekzotermi (HTE) denilen sicaklık yükselmesi görülür. Yüksek sicaklık ekzoterminin görüldüğü noktada don olayı hücre arasında meydana geldiğinden bu don öldürücü olarak kabul edilmez. Diğer taraftan benzer şekilde hücre içerisinde süper soğumuş suyun donması ile düşük sıcaklık ekzotermleri (LTE) meydana gelir ve bu noktada ki don öldürücüdür (Burke ve ark. 1976). Don zararı ile ilişkili oldukları bilinen (Nus ve ark. 1981) düşük sıcaklık ekzotermlerinin farklı organ veya dokularda meydana geldikleri sıcaklık değerleri ise termal analiz yöntemi ile belirlenerek don zararı tespit edilir. Yapılan termal analiz testleri sonucu çeşitlerin, 
yetiştiği bölgelerde iklim şartları ile çeşit ilişkisi ve farklı sıcaklık aralıklarındaki kış gözlerinin dona tolerans oranları Çizelge 3'de gösterilmiştir.

Çizelge 3. Kuzey yarımkürede dinlenmeye girişten göz patlamasına kadar asma gözlerine ait don toleransının

\begin{tabular}{|c|c|c|c|c|c|c|c|}
\hline Çeşit & $\begin{array}{l}\text { Ağustos } \\
\text {-Eylül } \\
\end{array}$ & $\overline{\text { Ekim }}$ & Kasım & Aralık & Ocak & Şubat & Mart \\
\hline \multicolumn{8}{|l|}{$V$. vinifera $\mathrm{L}$. } \\
\hline Cabernet Sauvignon & -5 ile -8 & -5 ile -12 & -9 ile -22 & -15 ile -25 & -17 ile -26 & -18 ile -25 & -16 ile -22 \\
\hline Chardonnay & & -10 ile -15 & -20 ile -29 & -17 ile -23 & -20 ile -30 & -17 ile -24 & -12 ile -22 \\
\hline Reisling & & -5 ile -15 & -10 ile -25 & -20 ile -23 & -22 ile -26 & -20 ile -27 & -10 ile -23 \\
\hline Viognier & & & & & -23 ile -24 & -22 ile -25 & \\
\hline Muscat Ottonel \#1 & & & & & -20 ile -24 & -20 ile -24 & \\
\hline \multicolumn{8}{|l|}{ V. labruscana L.H. } \\
\hline Bailey & -3 ile -15 & -12 ile -22 & -15 ile -26 & -20 ile -29 & -23 ile -27 & -21 ile -26 & -10 ile -25 \\
\hline \multicolumn{8}{|l|}{ Concord } \\
\hline V. riparia Michx. & -8 ile -12 & -15 ile -20 & -15 ile -22 & -25 ile -32 & -30 ile -42 & -25 ile -32 & \\
\hline $\begin{array}{l}\text { V. aestivalis Michx. } \\
\text { Norton (A) }\end{array}$ & & & & -28 ile -29 & -24 ile -25 & & \\
\hline \multicolumn{8}{|l|}{ Hybrids Vitis spp. } \\
\hline Seyval Blanc & & -21 & -22 & -23 ile -26 & -21 ile -22 & -17 ile -18 & \\
\hline Carlos (M) & & & -11 ile -13 & -18 ile -20 & -21 ile -22.5 & -22 ile -23 & \\
\hline Marechal Foch (V) & & & -20 ile -22 & -21 ile -27 & -28 & -27 & \\
\hline Mars $(\mathrm{L}, \mathrm{V})$ & & -10 ile -15 & -10 ile -20 & -19 ile -25 & -20 ile -26 & -15 ile- 25 & \\
\hline Saturn $(\mathrm{L}, \mathrm{V})$ & & -21 & -22 & -23 ile -26 & -21 ile -22 & -17 ile -18 & \\
\hline Summit $(\mathrm{M}, \mathrm{V})$ & & & -11 ile -14 & -18 ile -20 & -22 ile -23 & -22 ile -23 & \\
\hline
\end{tabular}

Kaynak: (Fennell 2004)

\section{Sonuç ve Öneriler}

Pek çok yaprağını döken meyve türünde olduğu gibi asmalarda da süpersoğuma olayının belirlenmesi islah ile bu türde düşük sıcaklıklara toleransın artırılmasında önemli gelişmeler sağlamıştır. Nitekim bu durum asmada termal analiz gibi yöntemlerin kullanılması ile düşük sıcaklıklara toleransın daha hızlı ve güvenilir olarak ölçülmesine olanak tanımıştır. Ayrıca asma doku ve organlarının düşük sıcaklıklara toleransının belirlenmesinde kullanılan ölçüm teknikleri ve bu tekniklerden elde edilen sonuçların tarla denemeleri ile benzer bulunması da dona toleransı anlamada büyük ilerlemelere neden olmuştur. Ancak sonraki çalışmalarda asma doku ve organlarında düşük sıcaklıklara toleransı artıran veya engelleyen faktörlerin neler olduğunun daha detaylı bir şekilde ortaya konulmasının gerekli olduğu kanaatine varılmıştır. Bu sayede dünya üzerinde daha kuzey bölgelerde asma yetiştiriciliğinin yapılabileceği ve mevcut yetişme alanları içerisindeki bölgelerde soğuk stresi risklerinin azaltılabileceği düşünülmektedir.

\section{Kaynaklar}

Ahmedullah M (1985). An analysis of winter injury to grapevines as a result of two severe winters in Washington. Fruit Var. J. 39:29-34.

Alleweldt G and Possingham JV (1988). Progress in grapevine breeding. Theor. Appl. Genet. 75:669-673.

Andrews PK Sandidge CR III Toyama TK (1984). Deep supercooling of dormant and deacclimating Vitis buds. Am J Enol Vitic 35:175-177

Barka EA and Audran JC (1997). Response of champenoise grapevine to low temperatures: Changes of shoot and bud proline concentrations in response to low tem- peratures and correlations with freezing tolerance. J. Hort. Sci. 72:577-582.

Bordelon BP, Ferree DC and Zabadal TJ (1997). Grape bud survival in the Midwest following the winter of 1993-1994. Fruit Varieties Journal 51:53-59.

Burke MJ, Gusta LV, Quamme HA, Weiser CJ and Li PH (1976). Freezing and injury in plants. Annu. Rev. Plant Physiol. 27:507-528.

Byers P Southwest Missouri State University. Personal communication (2008). 
Clark John R (2002). Louise Swenson. In Register of new fruit and nut varieties, List 41. W.R. Okie, editor. HortScience 37(2):256.

Clark John R (2004). Brianna. In Register of new fruit and nut varieties, List 42. W.R. Okie, editor. HortScience 39 (6):1510.

Clark JR and Moore JN (2002). A grapevine plant named 'Jupiter'. U.S. Plant Patent No. PP13,309.

Dami IB, Bordelon D, Ferree D, Brown M, Ellis R, Williams Doohen D. (2005). Midwest grape production guide. Ohio State University Extension Publication 919-05. On: http://ohioline.osu.edu/b919/0010.html.

Dami IE, Goffinet MC, Martinson TE uze Chien ML (2007). Winter injury to grapevines and methods of protection. Michigan State University Extension.

Domoto P (2008). Grape cultivars for consideration in Iowa. On: http://viticulture.hort.iastate.edu/info/pdf/ cultivars08.pdf. (Site no longer available).

FAO (2017). Erişim tarihi: 31.03.2017. http://www.fao.org/faostat/en/

Fennell A (2004). Freezing tolerance and injury in grapevines. In Adaptations and Responses of Woody Plants to Environmental Stresses. R. Arora (Ed.), pp. 201-235. Hawthorn Press, Binghamton, NY.

Fennell A and Hoover E (1991). Photoperiod influences growth, bud dormancy and cold acclimation in Vitis labruscana and V. riparia. J. Amer. Soc. Hort. Sci. 116:270-273.

Fiola JA, Pavlis GC and Tomasello C (1996). Lemberger and Rkatzitelli: high quality, cold hardy Vinifera for the East. American Journal of Enology and Viticulture. Vol. 47. No. 2: 232.

Fisher KH and Bradt OA (1985). 'Vanessa grape'. HortScience 20(1):147-148.

Friend AP, Trought CT and Creasy GL (2006) Impact of a spring frost event on the fruitfulness of Chardonnay Grapevines. (Poster). 6th International Cool Climate Symposium. Christchurch NZ.

Gao Z, Li J, Zhu H, Sun L, Du Y and Zhai H (2014). Using differential thermal analysis to analyze cold hardiness in the roots of grape varieties. Scientia Horticulturae, 174, 155-163.

Gerard PD and Schucany WR (1997). Locating exotherms in differential thermal anal- ysis with nonparametric regression. J. Agric. Biol. Environ. Stat. 2, 255-268.

Goffinet MC (2004). Anatomy of grapevine winter injury and recovery.Departmental Research Paper, Department of Horticultural Services, Cornell University, Geneva.

Grant TN and Dami IE (2015). Physiological and Biochemical Seasonal Changes in Vitis Genotypes with Contrasting Freezing Tolerance. American Journal of Enology and Viticulture.

Guo XW, Fu WH, Wang GJ (1989). Studies on cold hardiness of grape roots. Acta Hortic. Sin. 16, 17-22 (in Chinese).

Hamman RA (1993). Wine grape performance of 32 cultivars in western Colorado 1982-1986. Fruit Varieties Journal 47:59-63.

Hamman RA, Renquist AR and Hughes HG (1990). Pruning effects on cold hardiness and water content during deacclimation of Merlot bud and cane tissues. Am.. J. Enol. Vitic. 41:251-260.

Hart M (2008). Mount Ashwabay Vineyard and Orchard, Bayfield, WI. Personal communication.

Hawkins AJ (2007). Super gigantic Y2K winegrape glossary. On: http://www.wineloverspage.com/wineguest/wgg. html.

Hedrick UP, Booth NO, Taylor OM, Wellington R and Dorsey MJ (1908). The Grapes of New York: report of the New York agricultural experiment station for the year 1907. J.B. Lyon Company, Albany, New York.

Hemstad P and Luby J (2005). “Marquette”, a new wine grape, named in Minnesota. Wine East. Vol. 33, No. 4:7

Hemstead PR and Luby JJ (2000). Utilization of Vitis riparia for the development of new wine varieties with resistance to disease and extreme cold. Acta Hort. 528:487-490.

Hoover E and Hemstad P (2000). Growing grapes for home use. University of Minnesota Extension Publication F0- 1103.

Jones KS, Paroschy J, McKersie BD and Bowley SR (1999). Carbohydrate composition and freezing tolerance of canes and buds in Vitis vinifera. J. Plant Physiol.155:101-106.

Jones VG and Schultz HR (2016). Climate change and emerging cool climate wine regions. Wine \& Viticulture Journal. Pp. 1-2

Kaya Ö and Köse C (2017). Determination of resistance to low temperatures of winter buds on lateral shoot present in Karaerik (Vitis vinifera L.) grape cultivar. Acta Physiologiae Plantarum, 39(9), 209.

Keller M (2015). The science of grapevines-anatomy and physiology. Burlington, MA: Academic Press.

Keller M and Mills LJ (2007). Effect of pruning on recovery and productivity of cold-injured Merlot grapevines. Am. J. Enol. Vitic. 58, 351_357.

Keskin N Yağc1 A ve Keskin S (2013). Sivas-Gemerek Yöresi Üzümlerinin Bazı Kalite Özelliklerinin Belirlenmesi Üzerine Bir Araştırma. Yüzüncü Yıl Üniversitesi Tarım Bilimleri Dergisi, 23(3), 271278. 
Köse C and Güleryüz M (2009). Üzümlü İlçesi (Erzincan) Karaerik Üzüm Bağlarında 2007-2008 Kış Soğuklarının Kış Gözlerinde Yol Açtığı Zararlar. Atatürk Üniversitesi, Ziraat Fakültesi Derg., 40(1): 55-60.

Köse C and Kaya Ö (2017). Determination Of Resistance To Low Temperatures Of Winter Buds According To Position In Karaerik (V. vinifera L.) Grape Cultivar. International Journal of Scientific and Research Publications, 7(4):4-5

Luby J and Hemstad P (2006). A grapevine named ‘Frontenac gris'. U.S. Plant Patent No. PP16,478

Macgregor D (2007). Grapevine 'DM 8313-1'. U. S. Plant Patent No. PP17,773.

Marshall J (2008). Great River Vineyard and Nursery. Lake City, MN. Personal communication

Meiering AG, Paroschy JH, Peterson RL, Hostetter G and Neff A (1980). Mechanical freezing injury in grapevine trunks. Am. J. Enol. Vitic. 31:81-89.

Mills LJ, Ferguson JC, Keller M (2006). Cold-hardiness evaluation of grapevine buds and cane tissues. American Journal of Enology and Viticulture 57: 194 - 200.

Moore JN (1984). A grapevine named 'Reliance'. U.S. Plant Patent PP5,174.

Moore JN (1985). ‘Mars’ seedless grape. HortScience 20(2):313.

Moyer M, Mills L, Hoheisel G and Keller M (2011). Assessing and Managing Cold Damage in Washington Vineyards. WSU Extension at 1-800-723-1763 or http://pubs.wsu.edu.

Mullins CA (1986). Grape cultivar performance on the Tennessee Cumberland Plateau. Fruit Varieties J. 40:18-23.

Mullins MG, Bouquet A and Williams LE (1992). Biology of the Grapevine. Cambridge University Press, Cambridge, Cambridge, UK.

National Grape Registry (NGR) website: http://ngr.ucdavis.edu/. Supported by University of California Agriculture and Natural Resources Services, and the National Clonal Germplasm Repository of the USDA Agricultural Research Service.

Nus NL, Weigle JL and Schoradle JJ (1981). Superimposed amplified exothenn differential analysis system. Hort. Science 16:753-754.

Pagter M and Arora R (2013). Winter survival and deacclimation of perennials under warming climate: physiological perspectives. Physiol. Plant. 147, 75_87.

Paroschy JH, Meiring AG, Peterson RL, Hostetter G and Neff A (1980). Mechanical winter injury in grapevine trunks. Am. J. Enol. Vitic. 31:227-232.

Pierquet P and Stushnoff C (1980). Relationship of low temperature exotherms to cold injury in Vitis riparia Michx. Am. J. Enol. Vitic. 31:1-6.

Pierquet P, Stushnoff C and Burke MJ (1977). Low temperature exotherms in stem and bud tissues of Vitis riparia Michx. J. Amer. Hort. Sci. 102:54-55.

Plocher T (2007). Co-author of Northern Winework. Personal communication

Plocher T (2008). Co-author of Northern Winework. Personal communication

Plocher T and Parke B (2001). Northern Winework. Northern Winework, Inc. Hugo, MN. p. 156-157-158.

Plocher T and Parke B, (2008). Authors of Northern Winework. Personal communication

Pool RT (2002b). Dealing with Winter Cold Injury to Grapevine Canes and Trunks. Cornell Viticulture, http://www.nysaes.cornell.edu/hort/faculty/pool/trunkinjury/ tihtml/ trkinj table contents.html. Accessed May 15,

Quamme HA (1986). Use of thermal analysis to measure freezing resistance of grape buds. Can. J. Plant Sci. 66:945-952.

Quamme HA (1991). Application of thermal analysis to breeding fruit crops for increased cold hardiness. Hort Science, 26(5), 513-517.

Quamme HA (1995). Deep supercooling in buds of woody plants. Pp. 183-200 In: R.E. Lee Jr., G.J. Warren and L.V. Gusta (eds.), Biological Ice Nucleation and Its Applications. APS St. Paul, MN

Rajashekar CB and Burke MJ (1996). Freezing characteristics of rigid plant tissues. Development of cell tension during extracellular freezing. Plant Physiol. 111:597-603.

Reisch BI (2008).Cornell University. Personal communication

Reisch BI and Luce S. (2005). The less risky varieties, old and new. Presented at the Finger Lakes Grape Grower's Convention, Waterloo NY. 5 Mar. $2005 . \quad$ On http://www.nysaes.cornell.edu/hort/faculty/reisch/winehandout.html.

Reisch BI Pool RM and Einset J (1992). A grapevine named 'Chardonel'. U. S. Plant Patent No. PP7.860.

Reisch BI, Luce RS, Bordelon B and Henick-Kling T (2006). 'Corot noir'TM grape. New York’s Food \& Life Sciences Bulletin. No.159. New York State Agricultural Experiment Station, Geneva, NY. Cornell University, Ithaca, NY.

Reisch BI, Luce RS, Bordelon B and Henick-Kling T (2006). 'Valvin Muscat’TM Grape. New York’s food \& life sciences bulletin. No.161. New York State Agricultural Experiment Station, Geneva, NY. Cornell University, University, Ithaca, NY. 
Reisch BI, Luce Sand Henick-Kling T (2007). Recent releases and numbered selections from the Geneva grape breeding program. On: http://www.nysaes.cornell.edu/hort/ faculty/reisch/cultivars.html.

Reisch BI, Pool RM, Peterson DV, Martens MH and Henick-Kling T (2000). Wine and juice grape varieties for cool climates. Information Bulletin 233. Cornell CooperativeExtension. On: http://www.nysaes.cornell.edu/hort/ faculty/reisch/bulletin/wine/index2.html.

Schnabel BJ and Wample RL (1987). Dormancy and cold hardiness in Vitis vinifera L. cv. White Riesling as influenced by photoperiod and temperature. Am. J. Enol. Vitic. 38:265-272.

Slater JV, Warmund MR, George MR and Ellersieck MR (1991). Deacclimation of winter hardy 'Seyval Blanc’ grape tissue after exposure to 16 C. Scientia Horticulturae 45:273-285.

Smiley LA, Domoto P, Nonnecke G, Miller WW (2008). Cold climate cultivars: A review of cold climate grape cultivars - 'Baltica'. Iowa State University, Viticulture home page. http://viticulture.hort.iastate.edu/cultivars/cultivars.html (accessed: 02.04.2013)

Swenson E (1982). A grapevine named 'St. Croix'. U.S. Plant Patent No. PP4,928. (assigned to SwensonSmith Vines, Inc.).

Swenson E (1986). A grapevine named 'Esprit'. U.S. Plant Patent No. PP5,716 (assigned to Swenson-Smith Vines, Inc.).

Swenson E (1991). The Minnesota \#78 grape-lady of mystery. Fruit Varieties Journal Vol. 45 (1):6-8.

Swenson E, Pierquet P and Stushnoff (1980). 'Edelweiss' and 'Swenson Red’ grapes. HortScience 15 (1):100.

Turfan N Aktas LY and Guven A (2010). Low Night Temperature Tolerance Determining Traits Correlate with Paraquat Tolerance in Grapevine Genotypes. Yüzüncü Yll Üniversitesi Tarım Bilimleri Dergisi, 20(3), 194-200.

Wagner P (1988). On the trail of St. Vincent. Wine East Vol. 15 (6):8-9.

Whealy K (1993). Fruit, Berry and Nut Inventory. Seed Saver Publications. Decorah, IA. p. 335-336.

Wolf TK and Warren MK (2000). Crop yield, grape quality and winter injury of eight wine grape cultivars in Northern Virginia. J. Amer. Pomological Soc. 54:34-43.

Wolpert JA and Howell GS (1986a). Cold acclimation of Concord grapevines. III. Relationship between cold hardiness, tissue water content, and maturation. Vitis 25:151-159.

Zabadal TJ, Dami IE, Goffinet MC, Martinson TE and Chien ML (2007). Winter injury to grapevines and methods of protection, Michigan State University Publications on Grape Production, Michigan, USA, p. 36-37

Zhang J Wu X Niu R Liu Y Liu N Xu W Wang Y (2012) Cold resistance evaluation in 25 wild grape species. Vitis 51:153-160

Zraly K (2016). Complete Wine Course 2012 Edition - Book Review. Wine-Grower-News\#261. file://C:/Users/DellPC/Desktop/WineGrowerNews261_13Jan 2014. 